\title{
Physiological studies on pearl millet as affected by hybrids, plant density and fertility levels in semi arid environment
}

\author{
Bhagwat Singh Rathor, V.S. Rana*, R.K. Nanwal and Ramesh Vasist \\ Department of Agronomy, CCS Haryana Agricultural University Hisar- 125 004, India \\ *Corresponding author: V.S.Rana, Tel.: +919813212885, Fax: +91 1662-234613, E-mail: dryland@hau.ernet.in
}

\begin{abstract}
A field experiment was conducted at crop research farm, Chaudhary Charan Singh Haryana Agricultural University, Hisar, during the kharif seasons of 2004 and 2005 to find out suitable spacing for pearl millet hybrids along with $\mathbf{N} \& \mathbf{P}$ levels so as to increase the productivity of pearl millet. The experiment was laid out in split plot design allocating two hybrids and three plant densities in main plots and four fertility levels in sub plots replicated thrice. HHB-67-2 showed significantly higher dry matter accumulation plant ${ }^{-1}$ $(9.65 \%)$ at harvest, leaf area $\operatorname{plant}^{-1}(9.34 \%)$ at
\end{abstract} 55 DAS, leaf area index $(8.87 \%)$ and leaf area duration $(9.65 \%)$ at 41 to 55 DAS and crop growth rate (8.00) at 56 DAS to harvest over HHB-67 in first year. The fertility level $90 \mathrm{~kg} \mathrm{~N}+45 \mathrm{~kg}$ $\mathrm{P}_{2} \mathrm{O}_{5} \mathbf{h a}^{-1}$ recorded significantly higher dry matter accumulation plant $^{-1}$, leaf area plant ${ }^{-1}$, leaf area duration and crop growth rate over control and 30 $\mathrm{kg} \mathrm{N}+15 \mathrm{~kg} \mathrm{P}_{2} \mathrm{O}_{5}$ in both the crop seasons. Hybrid HHB 67-2 recorded significantly higher biological yield over HHB-67 in both the seasons. However $60 \mathrm{~kg} \mathrm{~N}+30 \mathrm{~kg} \mathrm{P}_{2} \mathrm{O}_{5} \mathrm{ha}^{-1}$ caused significant difference in biological yield over control and 30 $\mathrm{kg} \mathrm{N}+15 \mathrm{~kg} \mathrm{P}_{2} \mathrm{O}_{5} \mathrm{ha}^{-1+}$. HHB 67-2 recorded relatively higher value for consumptive water use and water use efficiency. The plant density of $45 x$ $12 \mathrm{~cm}$ produced significantly higher biological yield in both the seasons over $30 \times 12$ and $60 \times 12 \mathrm{~cm}$ densities.

Key words: Pearl millet, biological yield, leaf area index, leaf area duration, crop growth rate, water use efficiency.

\section{INTRODUCTION}

Pearl millet (Pennisetum glaucum) is the fourth most important crop after rice, wheat and sorghum in India.
About $97 \%$ of the acreage under pearl millet is rainfed, concentrated over arid and semi-arid regions of the country. The production of pearl millet is very low with existing cultivars. Some newly evolved hybrids are found to be more aggressive and responsive to fertilizers than the older ones. Intensive agriculture, being need of the hour, demands full exploitation of hybrids with available resources especially nutrients. Nutrients not only influence the physiological growth of the plant but also enhance below ground root proliferation. In this way replenishment of soil nutrients leads to more efficient water use. The quantity in terms of biological yield improved with application of fertilizers and maintenance of optimum plant density. Considering the immense importance of maintaining optimum plant density of newly evolved hybrids with proper fertilization under limited moisture conditions, an effort has been made to study the physiological parameters along with biological yield of pearl millet as affected by hybrids, plant density and fertility levels.

\section{MATERIALS AND METHODS}

The field experiment was conducted during kharif seasons of 2004 and 2005 at the Crop Research Farm, Chaudhary Charan Singh, Haryana Agricultural University, Hisar. The soil of the experimental field was sandy loam (Typic ustochrepts) with organic carbon $(0.46 \%)$ and available nitrogen (191 $\left.\mathrm{kg} \mathrm{ha}^{-1}\right)$, available phosphorus $\left(14 \mathrm{~kg} \mathrm{ha}^{-1}\right)$ and high non available potassium $\left(340 \mathrm{~kg} \mathrm{ha}^{-1}\right)$. The experiment was laid out in split plot design, keeping combinations of two hybrids (HHB 67 and HHB 67-2) and three plant densities [30 x $12 \mathrm{~cm}$ (2747777 plants ha $\left.{ }^{-1}\right), 45$ x $12 \mathrm{~cm}$ (185185 plant ha $\left.{ }^{-1}\right), 60$ x $12 \mathrm{~cm}$ (138888 plant ha $\left.{ }^{-1}\right)$ in main plots and four fertility levels (control, $30 \mathrm{~kg} \mathrm{~N}+15 \mathrm{~kg} \mathrm{P}_{2} \mathrm{O}_{5} \mathrm{ha}^{-1}, 60 \mathrm{~kg} \mathrm{~N}+30 \mathrm{~kg}$ $\left.\mathrm{P}_{2} \mathrm{O}_{5} \mathrm{ha}^{-1}, 90 \mathrm{~kg} \mathrm{~N}+45 \mathrm{~kg} \mathrm{P}_{2} \mathrm{O}_{5} \mathrm{ha}^{-1}\right)$ in sub plots. The total number of treatment combinations (24) were replicated three times. 
Whole $\mathrm{P}$ and half $\mathrm{N}$ as per treatments were drilled at the time of sowing. The remaining $\mathrm{N}$ was top dressed after thinning and gap filling (22 DAS). Pearl millet hybrids were sown on August 2, 2004 and July 20, 2005 as per plant density treatment using $5 \mathrm{~kg}$ seed per ha- $\mathrm{ha}^{-1}$. The recommended package of practices was followed in the crop for other agronomic operations. The total rainfall received during the crop season was 114.9 and $424.8 \mathrm{~mm}$ during kharif 2004 and 2005, respectively. The crop was harvested on October 7 and September 27 during 2004 and 2005 , respectively.

The dry matter accumulation in plants was recorded after drying them first in the sun and then in oven at 60 $\pm 5{ }^{\circ} \mathrm{C}$ to constant weight. The leaf area per plant was measured by LI 3000 area meter, LICOR Ltd., Nebraska, U.S.A. The leaf area index (LAI) was calculated by dividing leaf area by ground area.

Leaf area duration was calculated from leaf area index by using formula:

$\mathrm{LAD}=\frac{\mathrm{LAI}_{2}+\mathrm{LAI}_{1}\left(\mathrm{t}_{2}-\mathrm{t}_{1}\right)}{2}$

Where,

$\mathrm{LAI}_{2}=$ Leaf area index at $\mathrm{t}_{2}$

$\mathrm{LAI}_{1}=$ Leaf area index at $\mathrm{t}_{1}$

Crop growth rate was worked out by using formula

$\mathrm{CGR}=\frac{\mathrm{W}_{2}-\mathrm{W}_{1}}{\left(\mathrm{t}_{2}-\mathrm{t}_{1}\right)}$

Where, $\mathrm{W}_{1}$ and $\mathrm{W}_{2}=$ Dry weight of plants $(\mathrm{g})$ from a given land area at time $t_{1}$ and $t_{2}$, respectively.

$t_{2}-t_{1}=$ Time interval of observations (days)

Net area from each of the plots was harvested and sun dried separately. Total weight of these plants (stover + ear) from each net plot was recorded and computed as biological yield $\mathrm{ha}^{-1}$. Harvest index (HI) was computed by dividing economic yield by biological yield and multiplied by 100 . Attraction index was computed by dividing grain yield by stover yield and multiplied by 100 to express in per cent.

The consumptive use of water by pearl millet was worked out for different treatments by summing up the soil moisture depleted from the profile for different periods. The periodical effective rain fall was also added to compute consumptive water use of corresponding period. Consumptive water use was calculated by the formula given by Michael et al. (1977). Water-use efficiency (WUE) of the crop in different treatments was determined by dividing grain yield $(\mathrm{kg} / \mathrm{ha})$ by consumptive use of water ( $\mathrm{mm}$ ) and expressed in $\mathrm{kg} \mathrm{ha}^{-1}$ $\mathrm{mm}^{-1}$.

\section{RESULTS AND DISCUSSION}

\section{Growth}

Growth in terms of dry matter accumulation, leaf area index, leaf area plant ${ }^{-1}$, leaf area duration and crop growth rate varied under various treatments (Table 1). HHB-67-2 showed significantly higher dry matter accumulation plant $^{-1}(9.65 \%)$ at harvest, leaf area plant ${ }^{-1}(9.34 \%)$ at 55 DAS, leaf area index $(8.87 \%)$ and leaf area duration (9.65\%) at 41 to 55 DAS and crop growth rate (8.00) at 56 DAS to harvest over HHB-67 in first year. Differences in growth of different hybrids might be attributed to the differences in their genetic constitutions. Further, comparatively better growth of hybrid HHB-67-2 than HHB-67 might be due to its downy mildew resistant character. These results corroborate earlier findings reported by Parihar et al., (2005).

Plant density of $60 \times 12 \mathrm{~cm}$ resulted in an increase of $17.88,11.66$ and 15.25 per cent in dry matter accumulation plant $^{-1}$, leaf area plant ${ }^{-1}$ (55 DAS) and crop growth rate (55 DAS) at harvest, respectively over the density of $30 \times 12$ $\mathrm{cm}$ in first year. However, significantly higher leaf area index and leaf area duration was recorded when pearl millet was planted at $30 \times 12 \mathrm{~cm}$ over $60 \times 12 \mathrm{~cm}$. Thus, improvement in the performance of individual plant (dry matter accumulation, leaf area and crop growth rate) was brought about by decrease in plant density. Wider row spacing might be attributed to proper utilization of resources like moisture and nutrients which might have under utilized due to mutual plant competition developed by more plants in closer spacing. Overall improvement in the growth of individual pearl millet plants due to wider spacing have also been reported by Kumar et al. (2004).

Increasing levels of fertility significantly improved dry matter accumulation plant ${ }^{-1}$ and leaf area plant ${ }^{-1}$. The highest fertility level of $90 \mathrm{~kg} \mathrm{~N}+45 \mathrm{~kg} \mathrm{P}_{2} \mathrm{O}_{5}$ ha $^{-1}$ recorded significantly higher dry matter accumulation plant $^{-1}$, leaf area plant ${ }^{-1}$, leaf area duration and crop growth rate over control and $30 \mathrm{~kg} \mathrm{~N}+15 \mathrm{~kg} \mathrm{P}_{2} \mathrm{O}_{5}$ in both the crop seasons.

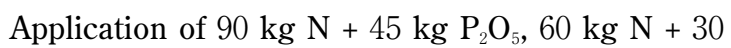
$\mathrm{kg} \mathrm{P}_{2} \mathrm{O}_{5}$ and $30 \mathrm{~kg} \mathrm{~N}+15 \mathrm{~kg} \mathrm{P}_{2} \mathrm{O}_{5}$ ha $^{-1}$ resulted in about $37.48,35.26$ and 19.21 per cent increase in dry matter accumulation over control, respectively. Adequate supply of fertilizers resulted in better root development, high photosynthetic rate, better utilization of carbohydrates in the synthesis of more protoplasm and higher accumulation of dry matter and overall improvement in the growth of pearl millet has been reported earlier by Sharma and Gupta (2001). Days taken to 50 \% flowering 
Table 1. Effect of various treatments on dry matter accumulation, leaf area, leaf area index, leaf area duration, crop growth rate, 50 \% flowering, biological yield, harvest index and attraction index.

\begin{tabular}{|c|c|c|c|c|c|c|c|c|c|c|c|c|c|c|c|c|c|c|}
\hline \multirow[t]{2}{*}{ Treatments } & \multicolumn{2}{|c|}{$\begin{array}{l}\text { Dry matter } \\
\text { accumulation } \\
\text { (g/plant) }\end{array}$} & \multicolumn{2}{|c|}{$\begin{array}{l}\text { Leaf area/ } \\
\text { plant }\left(\mathrm{cm}^{2}\right)\end{array}$} & \multicolumn{2}{|c|}{$\begin{array}{l}\text { Leaf area } \\
\text { index }\end{array}$} & \multicolumn{2}{|c|}{$\begin{array}{l}\text { Leaf area } \\
\text { duration } \\
\text { (days) }\end{array}$} & \multicolumn{2}{|c|}{$\begin{array}{c}\text { Crop } \\
\text { growth rate } \\
\text { (g/plant/ } \\
\text { days) }\end{array}$} & \multicolumn{2}{|c|}{$\begin{array}{c}\text { Days taken } \\
\text { to } 50 \% \\
\text { flowering }\end{array}$} & \multicolumn{2}{|c|}{$\begin{array}{c}\text { Biological } \\
\text { yield } \\
\text { (q/ha) }\end{array}$} & \multicolumn{2}{|c|}{$\begin{array}{c}\text { Harvest } \\
\text { index } \\
(\%)\end{array}$} & \multicolumn{2}{|c|}{$\begin{array}{l}\text { Attraction } \\
\text { index } \\
(\%)\end{array}$} \\
\hline & 200 & 2 & 2004 & 200 & 004 & 5 & 2004 & 20 & 2004 & 2005 & 2004 & 200 & 2004 & ? & 2004 & 2005 & 004 & 005 \\
\hline \multicolumn{19}{|l|}{ HYBRIDS } \\
\hline HHB-67 & 64.04 & 61.75 & 846.50 & 800.50 & 1.679 & 1.588 & 26.32 & 25.19 & 0.533 & 0.438 & 38.86 & 38.42 & 103.60 & 100.30 & 24.36 & 22.98 & 32.11 & 29.86 \\
\hline HHB-67-2 & 70.22 & 65.58 & 925.50 & 880.80 & 1.828 & 1.737 & 28.86 & 27.73 & 0.681 & 0.354 & 38.92 & 39.08 & 116.70 & 109.10 & 24.36 & 23.04 & 32.11 & 29.95 \\
\hline $\mathrm{SEm} \pm$ & 1.41 & 1.20 & 18.53 & 17.52 & 0.037 & 0.035 & 0.59 & 0.56 & 0.012 & 0.008 & 0.83 & 0.82 & 2.43 & 2.20 & 0.54 & 0.49 & 0.68 & 0.63 \\
\hline $\mathrm{CD}$ at $5 \%$ & 4.45 & 3.79 & 58.43 & 55.24 & 0.118 & 0.112 & 1.87 & 1.77 & 0.039 & 0.026 & NS & NS & 7.68 & 6.93 & NS & NS & NS & NS \\
\hline \multicolumn{19}{|l|}{ SPACING (cm) } \\
\hline $30 \times 12$ & 61.50 & 58.13 & 828.30 & 784.00 & 2.301 & 2.178 & 36.45 & 35.04 & 0.455 & 0.281 & 38.04 & 37.63 & 105.10 & 99.75 & 23.82 & 22.41 & 31.14 & 28.89 \\
\hline $45 \times 12$ & 67.40 & 63.75 & 904.70 & 856.00 & 1.675 & 1.585 & 26.05 & 24.96 & 0.616 & 0.417 & 38.50 & 38.50 & 123.60 & 117.70 & 24.80 & 23.44 & 32.86 & 30.63 \\
\hline $60 \times 12$ & 72.50 & 69.13 & 925.00 & 882.00 & 1.285 & 1.225 & 20.27 & 19.38 & 0.750 & 0.490 & 40.13 & 40.13 & 101.40 & 96.75 & 24.46 & 23.19 & 32.32 & 30.20 \\
\hline $\mathrm{SEm} \pm$ & 1.73 & 1.48 & 22.69 & 21.45 & 0.046 & 0.043 & 0.73 & 0.70 & 0.015 & 0.010 & 1.04 & 1.01 & 2.98 & 2.69 & 0.66 & 0.60 & 0.83 & 0.77 \\
\hline $\mathrm{CD}$ at $5 \%$ & 5.45 & 4.68 & 71.55 & 67.64 & 0.145 & 0.137 & 2.29 & 2.20 & 0.048 & 0.032 & NS & NS & 9.40 & 8.49 & NS & NS & NS & NS \\
\hline \multicolumn{19}{|l|}{ Fertility Levels } \\
\hline Control & 54.58 & 52.00 & 717.60 & 671.60 & 1.420 & 1.328 & 22.26 & 21.11 & 0.317 & 0.278 & 37.56 & 37.00 & 85.69 & 81.00 & 23.87 & 22.21 & 31.22 & 28.55 \\
\hline $30 \mathrm{~kg} \mathrm{~N}+15 \mathrm{~kg} \mathrm{P}_{2} \mathrm{O}_{5} \mathrm{ha}^{-1}$ & 65.07 & 63.17 & 869.30 & 815.30 & 1.721 & 1.612 & 27.18 & 26.13 & 0.457 & 0.403 & 38.33 & 38.17 & 109.30 & 102.80 & 24.48 & 22.98 & 32.29 & 29.84 \\
\hline $60 \mathrm{~kg} \mathrm{~N}+30 \mathrm{~kg} \mathrm{P}_{2} \mathrm{O}_{5} \mathrm{ha}^{-1}$ & 73.83 & 68.50 & 968.80 & 928.30 & 1.917 & 1.837 & 30.14 & 28.86 & 0.800 & 0.431 & 39.33 & 39.67 & 121.10 & 115.30 & 24.56 & 23.24 & 32.54 & 30.29 \\
\hline $90 \mathrm{~kg} \mathrm{~N}+45 \mathrm{~kg} \mathrm{P}_{2} \mathrm{O}_{5} \mathrm{ha}^{-1}$ & 75.04 & 71.00 & 988.30 & 947.30 & 1.956 & 1.873 & 30.78 & 29.73 & 0.854 & 0.472 & 40.33 & 40.17 & 124.60 & 119.80 & 24.52 & 23.63 & 32.36 & 30.95 \\
\hline $\mathrm{SEm} \pm$ & 1.23 & 1.06 & 16.27 & 15.47 & 0.033 & 0.031 & 0.51 & 0.47 & 0.013 & 0.009 & 0.72 & 0.70 & 1.85 & 1.95 & 0.40 & 0.42 & 0.59 & 0.55 \\
\hline $\mathrm{CD}$ at $5 \%$ & 3.54 & 3.35 & 46.69 & 44.41 & 0.094 & 0.089 & 1.48 & 1.36 & 0.036 & 0.025 & 2.04 & 2.02 & 5.30 & 5.59 & NS & NS & NS & 1.57 \\
\hline
\end{tabular}

Table 2. Effect of various treatments on consumptive use of water and water use efficiency.

\begin{tabular}{|c|c|c|c|c|}
\hline \multirow[t]{2}{*}{ Treatments } & \multicolumn{2}{|c|}{$\begin{array}{c}\text { Consumptive use of water } \\
\text { (mm) }\end{array}$} & \multicolumn{2}{|c|}{ 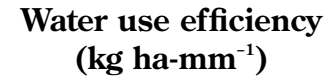 } \\
\hline & 2004 & 2005 & 2004 & 2005 \\
\hline \multicolumn{5}{|l|}{ HYBRIDS } \\
\hline HHB-67 & 203.6 & 237.7 & 12.40 & 9.74 \\
\hline НHB-67-2 & 205.4 & 240.5 & 13.85 & 10.49 \\
\hline \multicolumn{5}{|l|}{ SPACING (cm) } \\
\hline $30 \times 12$ & 208.1 & 242.7 & 11.99 & 9.21 \\
\hline $45 \times 12$ & 204.3 & 238.6 & 15.00 & 11.63 \\
\hline $60 \times 12$ & 201.0 & 235.4 & 12.40 & 9.55 \\
\hline \multicolumn{5}{|l|}{ FERTILITY LEVELS } \\
\hline Control & 198.1 & 232.9 & 10.30 & 7.72 \\
\hline $30 \mathrm{~kg} \mathrm{~N}+15 \mathrm{~kg} \mathrm{P}_{2} \mathrm{O}_{5} \mathrm{ha}^{-1}$ & 203.5 & 238.0 & 13.13 & 9.94 \\
\hline $60 \mathrm{~kg} \mathrm{~N}+30 \mathrm{~kg} \mathrm{P}_{2} \mathrm{O}_{5} \mathrm{ha}^{-1}$ & 207.2 & 241.6 & 14.37 & 11.10 \\
\hline $90 \mathrm{~kg} \mathrm{~N}+45 \mathrm{~kg} \mathrm{P}_{2} \mathrm{O}_{5} \mathrm{ha}^{-1}$ & 209.3 & 243.8 & 14.56 & 11.62 \\
\hline
\end{tabular}




\section{4}

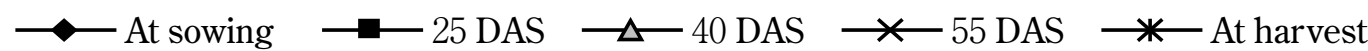

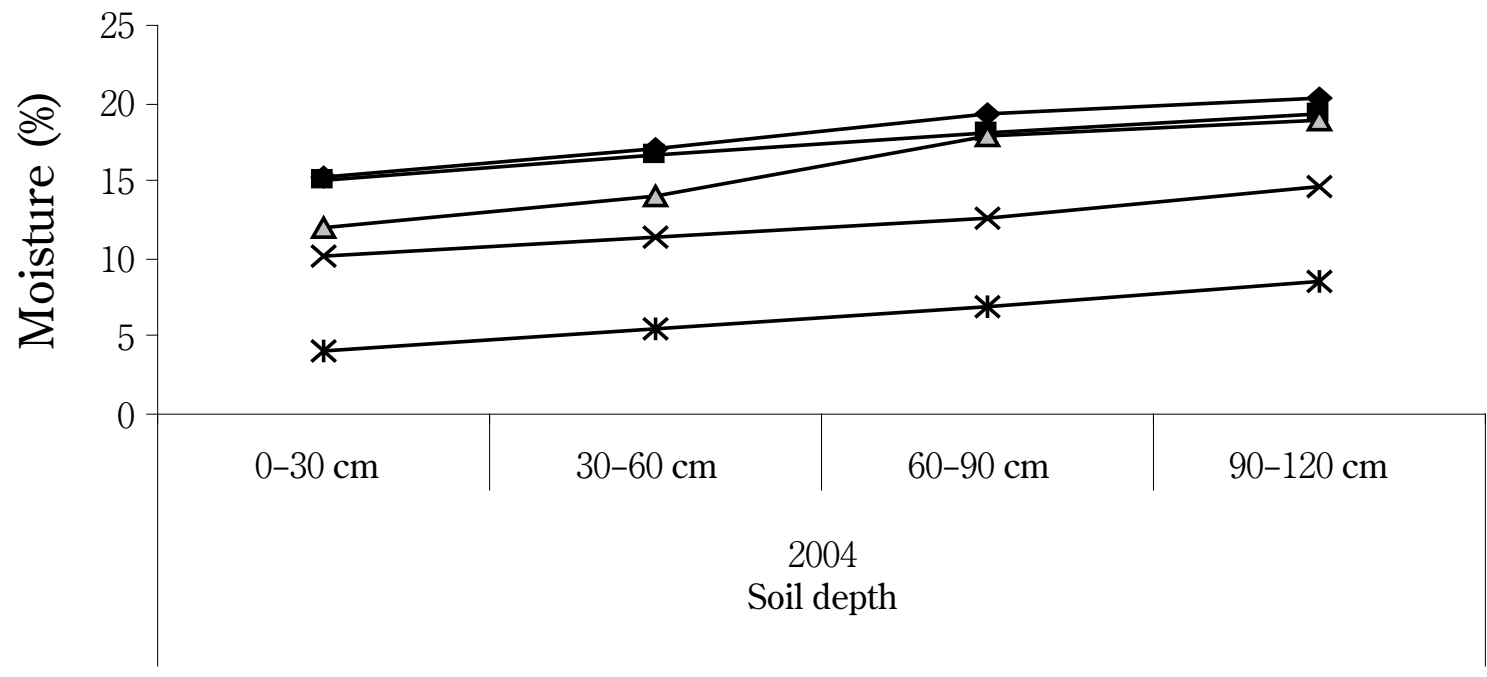

\section{5}

$\longrightarrow$ At sowing $\longrightarrow-25$ DAS $\triangle-40$ DAS $\longrightarrow 55$ DAS $\rightarrow$ At harvest

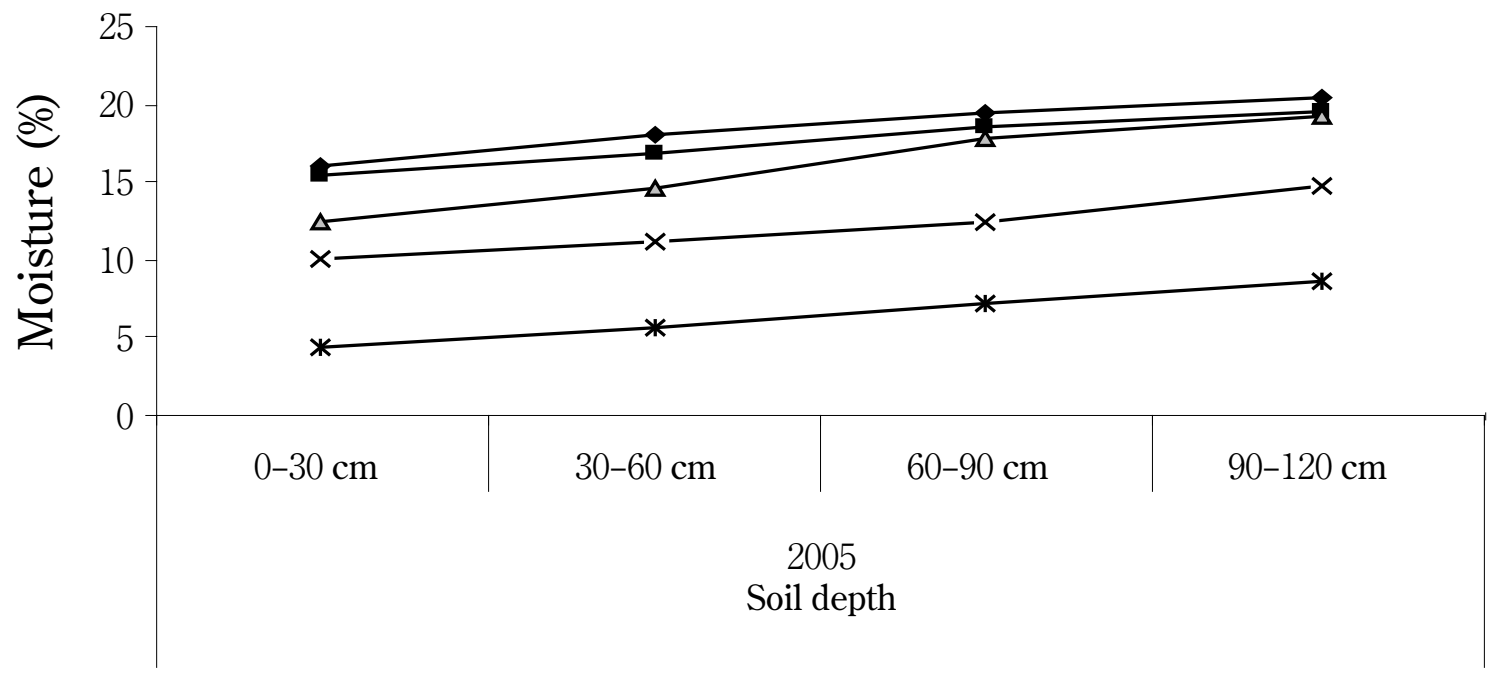

Fig. 1. Soil moisture studies from sowing to harvesting of the crop (2004 and 2005). 
was not influenced significantly by hybrids and spacing in both the seasons. taken The crop applied with $90 \mathrm{~kg} \mathrm{~N}+$ $45 \mathrm{~kg} \mathrm{P}_{2} \mathrm{O}_{5}$ ha $^{-1}$ took maximum number of days to reach at $50 \%$ flowering was significantly higher than control but at par with lower doses of fertility in both the crop seasons. Least days to $50 \%$ flowering were taken with control and was significantly lesser than all fertilizer treatments in both the seasons.

\section{Biological Yield}

Hybrid HHB67-2 recorded significantly higher biological yield over HHB-67 in both the seasons. Plant density 45 $\mathrm{x} 12 \mathrm{~cm}$ produced significantly higher biological yield in both the seasons over spacing $30 \times 12$ and $60 \times 12 \mathrm{~cm}$. The fertility level up to $60 \mathrm{~kg} \mathrm{~N}+30 \mathrm{~kg} \mathrm{P}_{2} \mathrm{O}_{5} \mathrm{ha}^{-1}$ resulted in significant difference in biological yield over control and $30 \mathrm{~kg} \mathrm{~N}+15 \mathrm{~kg} \mathrm{P}_{2} \mathrm{O}_{5} \mathrm{ha}^{-1}$ but beyond this level there was no significant response in biological yield. The results corroborate the findings of Kumar (2001). The hybrids, plant density and fertility levels failed to cause significant influence on harvest index of pearl millet. Similarly, hybrids and plant density failed to cause any significant influence in attraction index. Further, fertility levels in first year did not produce any significant difference in attraction index but in second year fertility level $90 \mathrm{~kg} \mathrm{~N}$ $+45 \mathrm{~kg} \mathrm{P}_{2} \mathrm{O}_{5}$ ha $^{-1}$ significantly increased attraction index over control and remained at par with $30 \mathrm{~kg} \mathrm{~N}+15 \mathrm{~kg}$ $\mathrm{P}_{2} \mathrm{O}_{5} \mathrm{ha}^{-1}$ and $60 \mathrm{~kg} \mathrm{~N}+30 \mathrm{~kg} \mathrm{P}_{2} \mathrm{O}_{5} \mathrm{ha}^{-1}$. Similar findings have been reported by Kumar et al. (2004).

\section{Water use studies}

Pearl millet hybrid HHB 67-2 recorded relatively higher value for consumptive use of water $(205.4 \mathrm{~mm}$ in 2004 and $240.5 \mathrm{~mm}$ in 2005) than HHB67 (203.6mm in 2004 and $237.7 \mathrm{~mm}$ in 2005). Water use efficiency was markedly higher with HHB67-2 than HHB67. Such variations in consumptive water use and water use efficiency might be viewed on the basis of differences in their growth in terms of leaf area and dry matter accumulation plant ${ }^{-1}$. The differences in the value of consumptive water use and water use efficiency of pearl millet hybrids were also reported by Kumar et al. (2003).

Plant density $30 \times 12 \mathrm{~cm}$ gave higher consumptive water use (Table 2) compared with $45 \mathrm{x} 12 \mathrm{~cm}$ and $60 \mathrm{x}$ $12 \mathrm{~cm}$ densities owing to larger crop canopy. However, 45 x $12 \mathrm{~cm}$ spacing resulted in higher water use efficiency. This can be explained on the basis of yield data (Table 1) which support the view that there was proper utilization of nutrient as well as moisture under optimum plant population. These results are in close conformity with those of Kaushik and Gautam (1991).

The nitrogen and phosphorus had favorable effect on consumptive water use and water use efficiency. The increasing levels of fertility increase the consumptive water use and water use efficiency. This might be due to increased in plant growth (Table 1). Besides this phosphorus might have increased the root volume thereby increasing consumptive water use and water use efficiency. Soil moisture increases with increasing soil depth during both the seasons. The moisture was higher at sowing and depleting slowly till harvest (Fig. 1). Similar findings also reported by Malik and Sharma (1984).

\section{REFERENCES}

Kaushik, S.K. \& Gautum, R.C. 1991. Effect of dryland practices and plant population on the productivity and moisture use efficiency of pearl millet. Indian Journal of Agronomy, 36: 228-233.

Kumar, M., Singh, H., Hooda, R.S., Khippal, A. \& Singh, T. 2003. Grain yield, water use and water use efficiency of pearl millet (Pennisetum glaucum) hybrids under variable nitrogen application. Indian Journal of Agronomy, 48: 53-58.

Kumar, M. 2001. Response of irrigated pearl millet hybrids to nitrogen. M.Sc. Thesis, CCS Haryana Agricultural University, Hisar.

Kumar, S., Kadian, V.S. \& Singh, R.C. 2004. Response of pearl millet hybrids to row spacing and nitrogen application. Annals Agriculture Research, 25: 68-70.

Malik, A.S. \& Sharma, H.C. 1984. Water use efficiency and phosphorus uptake of pearl millet as affected by moisture regimes, nitrogen levels and plant population. Haryana Agricultural University Journal Research, 14: 296-303.

Michael, A.M., Hukkeri, S.B. \& Singh, N.P. 1977. Estimating water requirement and irrigation management of crops in India. ICAR Monograph, 4: 91-92.

Parihar, M.D. Singh, Harbir, Hooda, R.S, Singh, V.P. \& Singh, K.P. 2005. Grain yield, water use, water use efficiency of pearl millet (Pennisetum glaucum) hybrids under varying nitrogen applications. Research on Crops, 6: 209-210.

Sharma, O.P. \& Gupta, A.K. 2001. Performance of pearl millet in different intercropping systems with varying levels of fertility. Annals Agricultural Research, 22: 267-270. 
Received 23 ${ }^{\text {rd }}$ Mar. 2007

Accepted $11^{\text {th }}$ Oct. 2007 